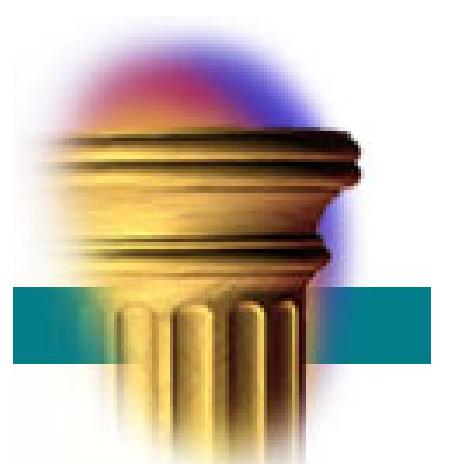

\title{
0 \\ and \\ Perceived Competition in Agricultural Lending: Stylized Facts and an Agenda for Future Research
}

$\frac{\pi}{0}$

\author{
Todd H. Kuethe, Chad Fiechter, and
}

David Oppedahl

October 2021

WP 2021-16

https://doi.org/10.21033/wp-2021-16

${ }^{*}$ Working papers are not edited, and all opinions and errors are the responsibility of the author(s). The views expressed do not necessarily reflect the views of the Federal Reserve Bank of Chicago or the Federal Reserve System. 


\title{
Perceived Competition in Agricultural Lending:
}

\section{Stylized Facts and an Agenda for Future Research}

\author{
Todd H. Kuethe ${ }^{1}$, Chad Fiechter ${ }^{1}$, and David Oppedahl ${ }^{2}$ \\ ${ }^{1}$ Department of Agricultural Economics, Purdue University, West Lafayette, Indiana, USA \\ ${ }^{2}$ Economic Research Department, Federal Reserve Bank of Chicago, Chicago, Illinois, USA
}

Forthcoming: Agricultural Finance Review

\begin{abstract}
Purpose: This study examines agricultural lending by commercial banks and the competition they face from the Farm Credit System and non-traditional lenders, including merchants, dealers, and other input suppliers.

Design/methodology/approach: We construct a measure of commercial banks' perceived competition with FCS or non-traditional lenders using the individual responses to the Federal Reserve Bank of Chicago's Land Values and Credit Conditions Survey between 1999 and 2019. Through regression analysis of an unbalanced panel of survey responses, we present a number of stylized facts on the relationship between perceived competition and farm loan rate spreads, collateral requirements, loan delinquencies, and expected lending volumes.
\end{abstract}

Findings: Our analysis shows that the two sources of competition have very different effects on commercial bank lending terms, loan portfolio riskiness, and expected loan volumes. With these results in mind, we offer a number of suggestions for future research.

Originality/value: We leverage the unique characteristics of the Land Values and Credit Conditions Survey to examine the competition with non-traditional lenders that cannot be observed using administrative data.

Keywords: competition, agricultural lending, non-traditional lenders

JEL Codes: Q14, G21 


\section{Introduction}

Farmers require short-term loans to finance their capital base, to conduct marketing and production plans, and to provide short-term liquidity to respond to risk. Farmers acquire shortterm loans or operating credit from a variety of financial institutions, such as commercial banks and Farm Credit System (FCS) lenders, as well as non-financial institutions, such as merchants, dealers, and other input suppliers. Many of the non-financial institutions are considered "nontraditional lenders" because their primary contact with agricultural producers has historically been for goods and services, other than credit (Sherrick et al., 1994). Tseng (2020) suggests four reasons that non-traditional lenders offer credit: (i) to stimulate sales or solidify market share of their primary products or services, (ii) to generate profit from credit sales, (iii) to utilize information advantages, and/or (iv) to reduce the transaction and contracting costs by providing convenience for borrowers.

In recent years, the supply of short-term credit from non-traditional lenders has increased (Brewer et al., 2019). However, little is known about the competition between non-traditional and "traditional" lenders, even though the potential for competition is well established in the existing literature (Sherrick et al., 1994). Competition in agricultural lending markets has been an important policy concern for more than 100 years. The FCS, for example, was established by Congress in 1916 to increase competition in agricultural lending markets in an effort to improve credit market efficiency, lower transaction costs, and reduce asymmetric information between farmers and lenders (Lee and Irwin, 1996; Jensen, 2000).

Previous studies have examined the competition between FCS lenders and commercial banks (Hubbs and Kuethe, 2017; Turvey et al., 2020), but the competition between traditional and non-traditional lenders is relatively unexplored due to the lack of sufficient data. The lending relationships between farmers and non-traditional lenders are not regulated in the same way as those with commercial banks or FCS lenders (Sherrick et al., 1994; Barry et al., 2000; Brewer et al., 2019). As a result, non-traditional lending is not captured by administrative data or mandatory reporting requirements, such as those of the Federal Financial Institutions Examination Council (FFIEC) or Farm Credit Agency (FCA). For example, the USDA Economic Research Service (ERS) provides the most comprehensive snapshot of debt in the U.S. agricultural sector (USDA Economic Research Service, 2021). While the USDA separately reports outstanding debt levels for commercial banks and FCS lenders, non-traditional lenders are grouped within the broader category of "individuals and others." ERS assembles outstanding debt from commercial banks and FCS lenders using mandatory call report data, but debt from individuals and others is primarily obtained from surveys of farmers (Briggeman et al., 2012).

This paper explores the competitive pressures commercial banks face from both FCS and non-traditional lenders in the market for farm operating loans. We exploit unique information 
provided by the Federal Reserve Bank of Chicago's Land Values and Credit Conditions Survey to construct a novel measure of commercial bankers' perceptions of competitive pressure from FCS and non-traditional lenders. Our measure of perceived competition has a number of advantages over traditional measures of lending market competition and overcomes recognized challenges of measuring competition in agricultural lending markets (Morris et al., 2015). We use this novel measure of perceived competition to explore a number of characteristics of lending in competitive markets derived from the existing literature and present a number of stylized facts. Specifically, we examine the impact of perceived competition on loan rate spreads, collateral requirements, loan delinquencies, and expected loan volumes. These stylized facts provide the basis for a proposed research agenda on competition in the agricultural credit markets between traditional and non-traditional lenders.

The remainder of our study is organized as follows. First, Section 2 provides an overview of the literature on competition in lending markets and key institutional features of agricultural lending. This section highlights why traditional measures of competition in lending markets are not well suited for examining the impact of non-traditional lenders on traditional lenders, such as FCS or commercial banks. Then, Section 3 introduces our measure of perceived competition in agricultural credit markets. The measure exploits subjective information from the Land Values and Credit Conditions Survey which provides information that cannot be obtained through traditional competition measures. Section 4 presents a number of stylized facts on the impacts of perceived competition on loan rate spreads, collateral requirements, loan delinquencies, and expected loan volumes. These stylized facts contrast the impacts of perceived competition with FCS and non-traditional lenders, such as differences in commercial banks' response and loan portfolio risk. These stylized facts provide important information on an area that has received limited empirical treatment in the literature, but our empirical analysis is subject to a number of limitations and constraints. As a result, Section 5 closes with a proposed agenda for future research based on our stylized facts.

\section{Background}

Economists continue to debate the degree to which competition in lending markets is desirable. At one extreme, the "competition-fragility hypothesis" posits that more competition is bad because it places downward pressure on bank profits. The downward pressure on bank profits reduces "charter" value and creates incentives for excessive risk taking among lenders 3 (Keeley, 1990). Increased competition is also believed to undermine lenders' incentives to invest in information acquisition (Claessens, 2009). Thus, increased competition makes the financial system more fragile (Bushman et al., 2016).

At the other extreme, the "competition-stability hypothesis" posits that more competition is good because it encourages lenders to lower interest rates which in turn leads to more profitable borrowers and lower credit risks for banks (Boyd and De Nicolo, 2005). In addition, it is believed that increased lending competition has "generally led to greater product differentiation, lower cost of financial intermediation, more access to financial services, and enhanced stability" (Claessens, 2009, pp. 84). The greater access to financial services is particularly attractive for agricultural producers who frequently cannot access the level of credit 
they require or desire (Bierlen and Featherstone, 1998; Barry et al., 2000; Briggeman et al., 2009). Thus, competition makes the financial system more stable or resilient (Bushman et al., 2016).

Martinez-Miera and Repullo (2010) present a synthesis of the "competition-fragility hypothesis" and "competition-stability hypothesis" dichotomy. According to Martinez-Miera and Repullo, competition and stability/fragility share a U-shaped relationship based on the initial level of competition. When a market is initially monopolistic, higher competition leads to increased stability by lowering the risk of borrower bankruptcy, as well as the risk of bank default. When a market is initially competitive, higher competition leads to increased fragility by lowering the revenue from performing loans and increasing the risk of bank default. Both cases presume that increased competition leads to lower interest rates. In the monopolistic case, lower interest rates are associated with a "risk-shifting effect," but in the competitive case, lower interest rates are associated with a "margin effect."

\subsection{Measuring Competition}

It is difficult to measure competition in credit markets. Economic theory suggests that competitive markets prevent firms from setting market prices above the marginal cost of production. In a market without barriers to entry or exit, rival firms will enter the market when incumbent firms earn abnormal profits (market prices above marginal cost). When incumbent firms respond by returning prices to levels consistent with normal profits, the new firms will exit. As a result, economists have derived a number of ways to measure market competition related to firms' entry and exit decisions, as well as the relationship between firms' market prices and their marginal costs of production. Each of these measures offer a number advantages and disadvantages in measuring competition in credit markets.

Claessens (2009) identifies three dominate approaches to measure competition in lending markets. The first set of measures are related industry composition and concentration. Financial regulators typically measure competition following the Structure-Conduct- Performance (SCP) paradigm (Morris et al., 2015). The SCP paradigm posits that market structure influences firms' conduct, and firms' conduct influences their performance. Conduct and performance can be difficult for regulators to observe or measure. However, it is believed that as a market becomes more concentrated, firms' conduct is more likely to approach that of the monopolist. As a result, financial regulators often evaluate market competition by the number of lending institutions or measures of financial system concentration, such as the Herfindahl index (Claessens, 2009). The number of lending institutions, however, is a poor measure of industry structure because it often differs substantially from the industry concentration (Jiménez et al., 2013). Further, industry concentration can be an inadequate indicator of competition in banking systems (Claessens and Laeven, 2004; Berger et al., 2017). Economic theory suggests markets with only a single firm can be competitive, if the firm's potential for monopolist behavior is limited by the potential entry of rival firms.

As a result, the second approach to measure competition in lending markets relies on regulatory indicators of firm entry and exit (Claessens, 2009). These studies typically exploit 
natural experiments provided by changes in entry requirements or activity restrictions. Alternatively, studies examine variations in entry requirements or activity restrictions across markets. Limits in data availability or the occurrence of natural experiments therefore limit the widespread adoption of these measures.

The third approach for measuring competition in lending markets relies on proxy measures of the link between lenders marginal costs (or input prices) and output prices (Claessens, 2009). While these proxy measures have been widely applied in other markets, they can be difficult to apply to credit markets because lenders' production function is unclear (Claessens, 2009). In addition, lenders have a tendency to produce and sell bundles of services. Further, the estimation of cost-transfer functions in many markets is hampered by weak or volatile data.

\subsection{Competition in Agricultural Credit Markets}

Previous studies have used each of these three approaches to examine competition in agricultural credit markets. Hubbs and Kuethe (2017) and Turvey et al. (2020) use the share of total farm debt from commercial banks and FCS lenders to measure the competition between the two categories of institutions. Both studies suggest that the competitive balance between commercial banks and FCS lenders shifts over time, particularly in periods of financial stress. Morris et al. (2015) examine the influence of FCS lenders on market structure analysis of agricultural commercial banks. The authors find that traditional competition measures, such as the number of competitors or concentration, may understate market's competitiveness if FCS lenders are excluded. They show that including both FCS and commercial banks is difficult due to mismatch of market definitions across the institution's respective regulators. Kandilov and Kandilov (2018) follow the regulatory indicator approach by examining the impact of interstate banking deregulation on farm financial conditions. While Kandilov and Kandilov (2018) demonstrates a number of ways in which farms benefit from deregulation, the work did not directly estimate the change in competitiveness across lending institutions. Finally, Regmi and Featherstone (2021) more directly explored the impacts of competition on commercial banks using a Lerner index of the relationship between bank assets and marginal costs. The study, however, is unable to identify the source of competitive pressure.

\section{Perceived Competition}

Bushman et al. (2016) argue that all of the traditional measures outlined by Claessens (2009) fail to capture a number of important components of competition in lending markets. Bushman et al. (2016) argue that a preferred measure of credit market competition would capture managers' current perceptions of competitive pressures from any and all sources, including potential entrants and non-bank competitors. Further, such a measure would capture the evolution of competitive pressures that are not yet fully reflected in a bank's past performance. To this end, Bushman et al. (2016) construct a measure of perceived competition derived from text-analysis of banks' mandatory 10K filings (following Li et al., 2013).

We develop an alternative measure of perceived competition that captures managers' current perceptions of competitive pressures from non-bank competitors that may not yet fully 
reflected in a bank's performance. Our measure is similar to survey-based measures of competition used to study competition in other sectors of the economy but have received limited use in lending markets (Haskel and Martin, 1994; Nickell, 1996; Dedman and Lennox, 2009). Moss et al. (1997), which used survey methods to measure commercial banks perceived competition with other banks, is the notable exception.

We construct a binary indicator of perceived competition derived from multiple questions from the Federal Reserve Bank of Chicago's Land Values and Credit Conditions Survey. The survey collects information on current and expected credit market conditions and agricultural land values from agricultural bankers throughout the Federal Reserve's Seventh District. As shown in Figure 1, the Seventh District spans the northern portions of Illinois and Indiana, southern Wisconsin, the lower peninsula of Michigan, and the entire state of Iowa. The survey population includes all member banks at which farm loans as a share of total loans exceeded a threshold that was established in 1972 (Federal Reserve Bank of Kansas City, 2020). A threshold of $25 \%$ was applied in all states except Michigan, where a threshold of $10 \%$ was applied. The Seventh District accounts for approximately $25 \%$ of the nation's agricultural banks (Federal Reserve Bank of Kansas City, 2020). Each quarter, the survey is mailed to the bank's chief executive and emailed to bank representatives. The survey is completed by either the chief executive or one of the bank's agricultural loan officers or farm managers.

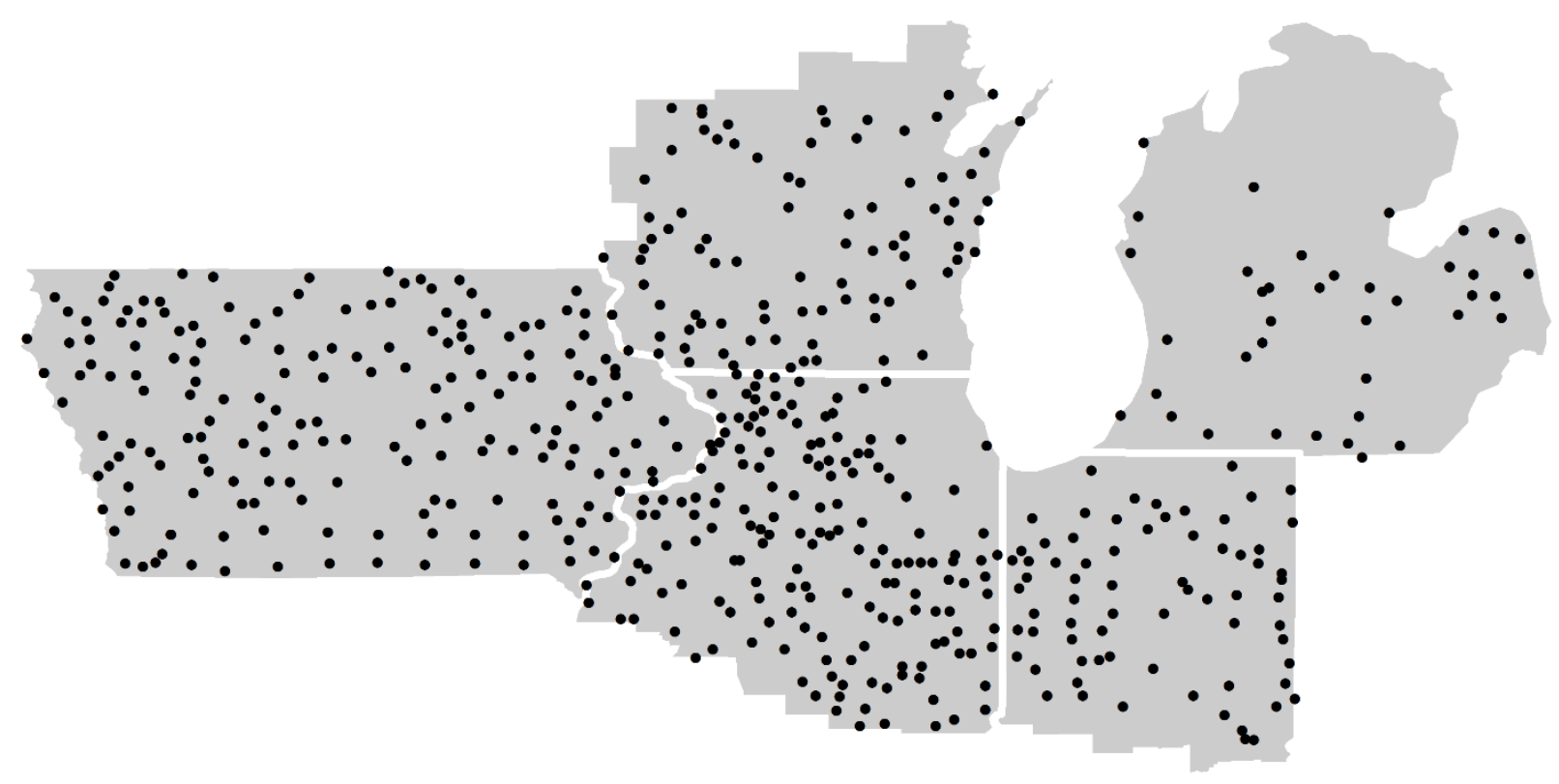

Source: Federal Reserve Bank of Chicago

Figure 1: Land Values and Credit conditions Survey Respondent Banks

The quarterly survey contains a number of standard questions that are asked every quarter, as well as a set of special questions that change throughout the year to reflect seasonal 
issues in the agricultural sector. Our measure of perceived competition is derived from a series of responses to the following question:

VI. How does the amount of farm loans made by lenders in your area so far this year compare with normal?

$$
\text { Higher (1) ___ ; Lower (2) __ ; Same (3) ___. }
$$

Respondents report the perceived loan volumes for a number of lender types, including (i) Farm Credit System lenders; (ii) merchants, dealers, and other input suppliers; and (iii) their bank. Responses for Farm Credit System lenders and their bank are elicited for both farm operating loans and farm mortgage loans. Given that our primary interest is perceived competition with FCS and non-traditional lenders, we limit our analysis to farm operating loans. This question appears in the second quarter survey, administered in July. This form of ordinal or quantitative response questions are not unique to the Land Values and Credit Conditions Survey but are common form of elicitation in lender surveys by the Federal Reserve or other central banks. Previous research shows that these lending surveys are good predictors of aggregate bank lending (Lown and Morgan, 2006; Bassett et al., 2014; Ciccarelli et al., 2015), as well as the supply and demand of credit (Del Giovane et al., 2011).

We construct an unbalanced panel of Land Values and Credit Conditions Survey responses from 1999 through 2019, which consists of 4,479 responses from 597 banks. As shown in Figure 2, farm sector non-real estate debt nearly doubled between 1999 and 2019, from $\$ 80.5$ billion to $\$ 151.8$ billion (USDA Economic Research Service, 2021). Over this period, nonreal estate debt from commercial banks increased by $70.1 \%$, from $\$ 41.4$ billion to $\$ 70.3$ billion, but commercial banks' market share for non-real estate loans fell, from 51.4\% in 1999 to $46.3 \%$ in 2019. Conversely, non-real estate debt from FCS lenders grew by $241.4 \%$, from $\$ 15.5$ billion in 1999 to $\$ 53.0$ billion in 2019, and FCS market share increased from $19.3 \%$ in 1999 to $34.9 \%$ in 2019. In addition, non-real estate debt provided by "individuals and others" - which includes non-traditional lenders - increased from $\$ 19.4$ billion in 1999 to $\$ 24.7$ billion in 2019 (a 27.5\% increase). ${ }^{1}$

Aggregate ordinal responses are typically summarized using a balance statistic, calculated as the share of respondents reporting "higher" less the share of respondents reporting "lower." Thus, the balance statistic is positive when the share of respondents who report higher than normal loan volumes is greater than the share of respondents who report lower than normal loan volumes. Figure 3 plots the balance statistics using the full set of responses for the three types of institutions: Farm Credit System lenders (dashed line); merchants, dealers, and other input suppliers (dotted line); and respondent's bank (solid line). For both FCS and input suppliers, the balance statistic is positive in all years, which suggests that commercial banks respondents perceive increasing loan volumes from competing lender types. By contrast, the balance statistic for the respondents' own farm operating loans fluctuates greatly over the study

\footnotetext{
${ }^{1}$ These changes are observed in spite of USDA's change in lender definitions in 2012. Beginning in 2012, farm sector debt held by savings associations is classified under commercial banks instead of the "individuals and others" category.
} 


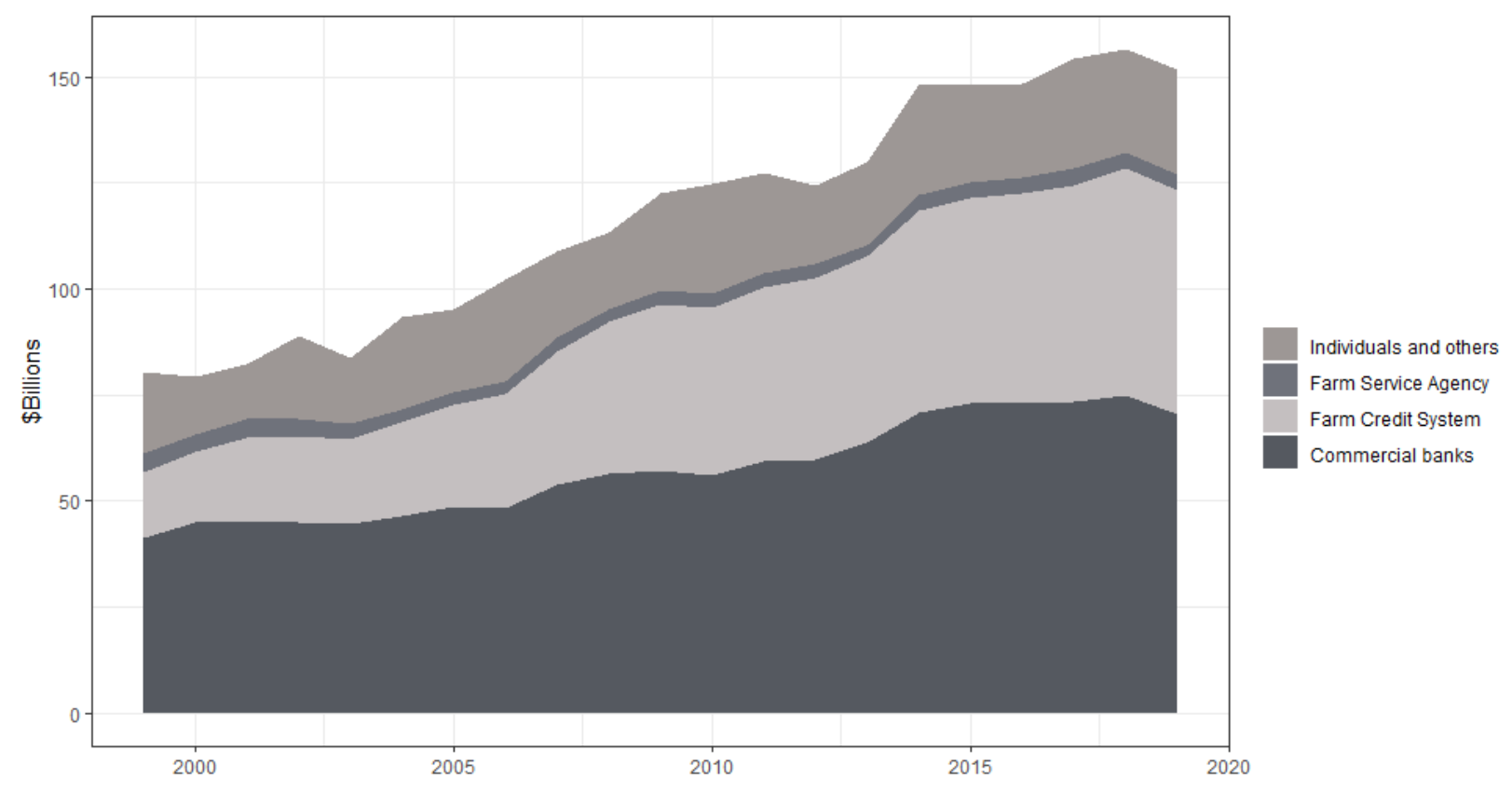

Source: USDA Economic Research Service (2021)

Figure 2: Farm non-real estate debt by lender type, 1999-2019

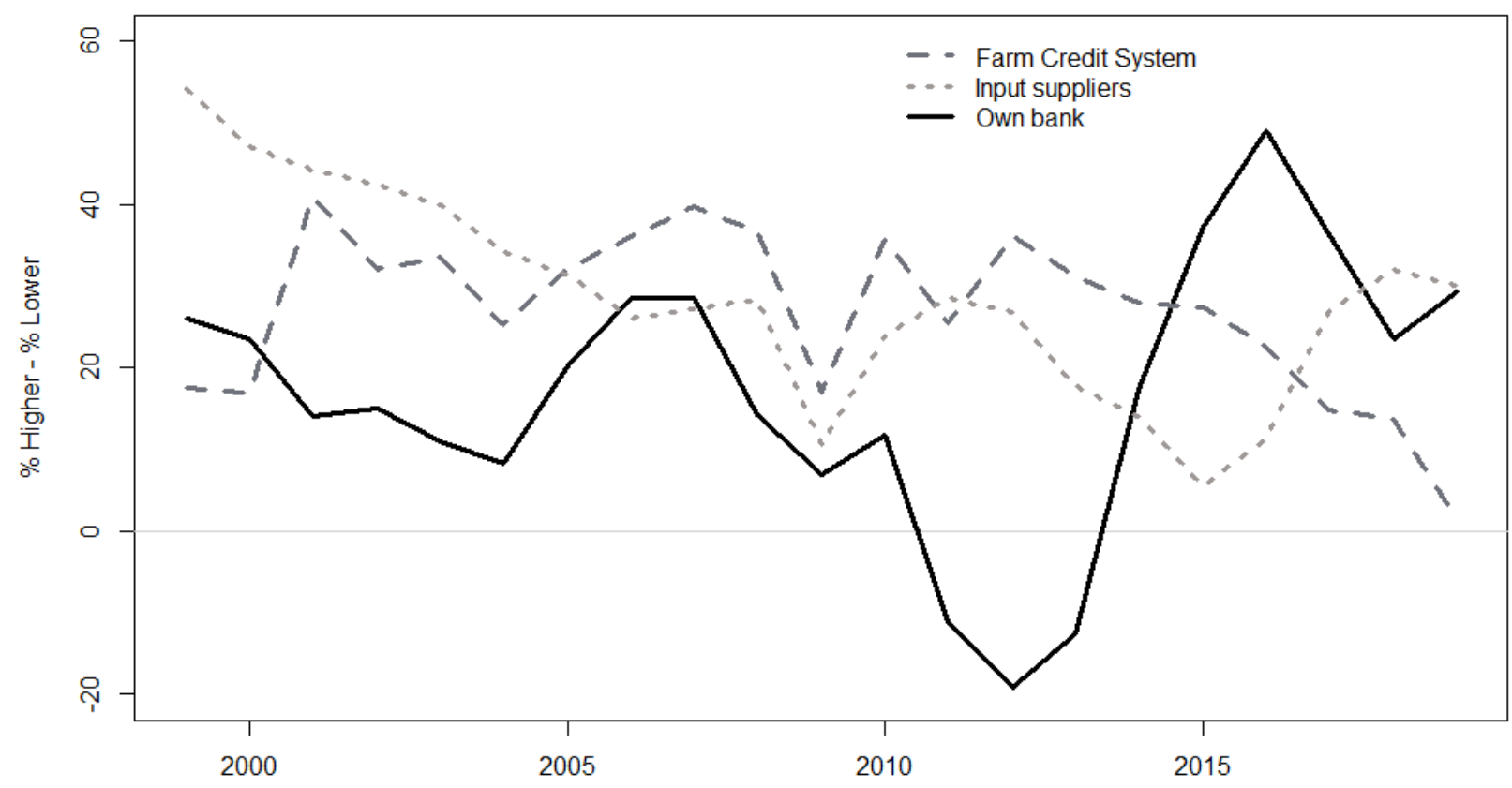

Source: Federal Reserve Bank of Chicago

Figure 3: Operating loan volume balance statistic, 1999-2019

Note: Balance Statistic is calculated as the share of respondents reporting "higher" less the share of respondents reporting "lower" 
period and was negative between 2011 and 2013. The negative balance statistic between 2011 and 2013 suggests respondents' loan volumes fell below normal lending levels during this period, but was above normal in all other years. The combined information in Figures 2 and 3 provide evidence of changes in the competitive pressure commercial banks likely perceive from FCS and non-traditional lenders.

We construct an indicator of perceived competition using respondents' subjective opinion of the volume of operating loans at their bank and those by FCS and non-traditional lenders. For each respondent, the indicator takes the value of 1 if the respondent reports their own operating loan volume as "lower" or "same" compared to normal and "higher" for the competing institution. For example, as shown in Figure 3, respondents generally report operating loan volumes above normal for FCS lenders in their area. We classify commercial bank respondents as competing with FCS lenders when they report "higher" than normal operating loan volumes at FCS but "lower" or "same" at their own bank. Thus, banks perceive competition with FCS lenders when they perceive a loss in market share relative to FCS lenders, even if they are maintaining normal lending volumes. We construct three indicator variables: (i) perceived competition with FCS lenders, (ii) perceived competition with non-traditional lenders, (iii) perceived competition with either FCS or non-traditional lenders.

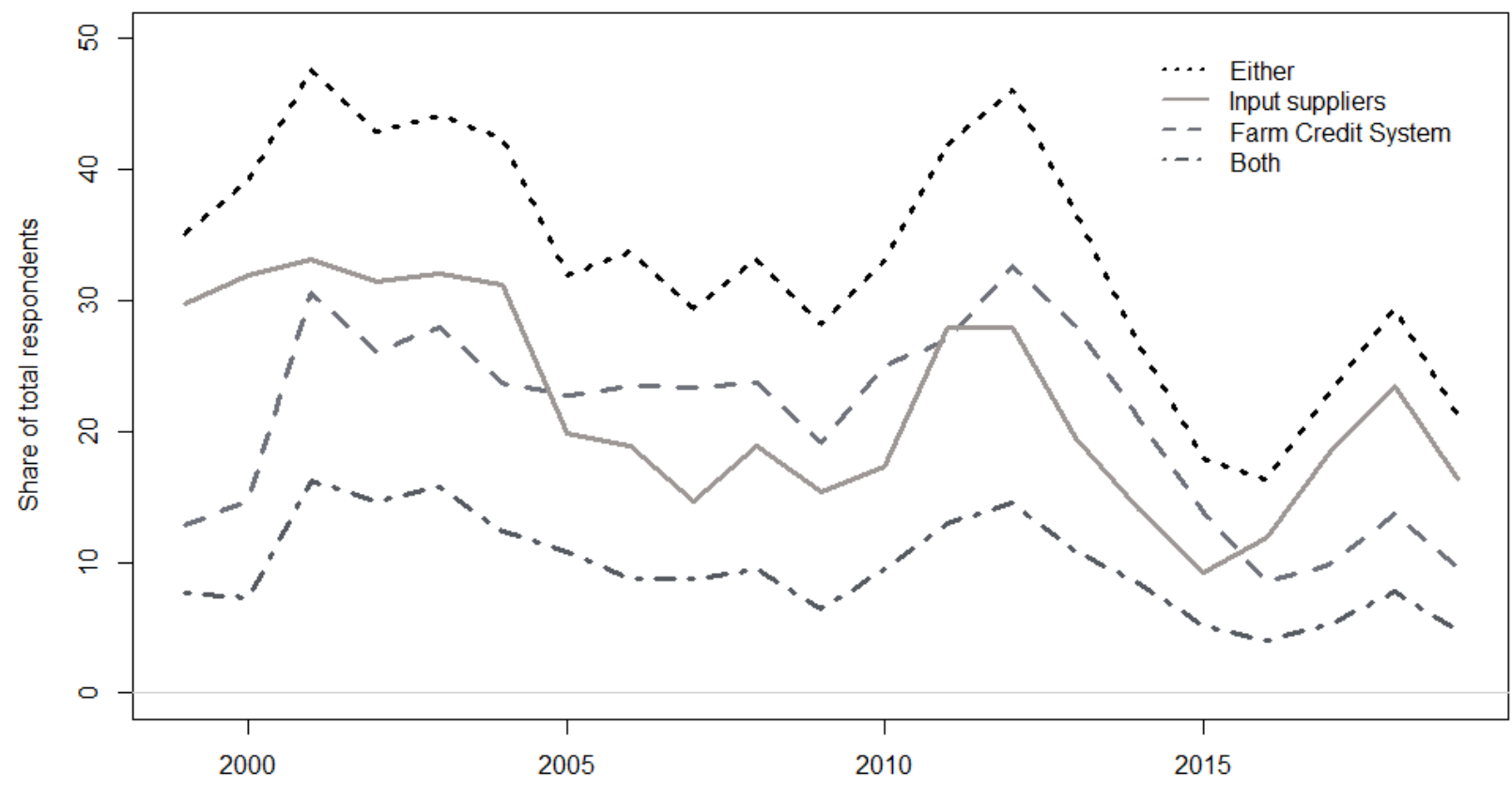

Source: Federal Reserve Bank of Chicago

Figure 4: Share of respondents competing with other lenders, 1999-2019

Figure 4 plots the share of respondents classified as under perceived competition with FCS (solid line) or non-traditional lenders (dashed line). Our measure suggests that, between 1999 and 2019 , on average $20.1 \%$ of respondents were under perceived competitive pressure from FCS lenders, and $22.0 \%$ of respondents were under perceived competitive pressure from 
non-traditional lenders. The share of respondents under competitive pressure from FCS lenders peaked in $2012(32.6 \%)$, and the share of lenders under competitive pressure from nontraditional lenders peaked in 2001 (33.2\%). In addition, the relative competitive threat from FCS or non-traditional lenders fluctuated throughout the observation period. Between 1999 and 2004, non-traditional lenders appear to be a larger competitive threat, as the share of respondents under competitive pressure form non-traditional lenders exceed the share of respondents under competitive pressure from FCS lenders. However, between 2005 and 2015, FCS lenders appear to be a greater source of perceived competition compared to non-traditional lenders. At the end of the observation period, from 20016 through 2019, non-traditional lenders were again a larger competitive threat, relative FCS lenders.

The dashed line in Figure 4 represents the share of respondents who express perceived competition with either FCS or non-traditional lenders. On average, approximately one third (33.3\%) of respondents express competitive pressure from either FCS or non-traditional lenders between 1999 and 2019. The share of banks under competitive pressure from either category of lenders peaked in 2001 (47.6\%) and 2012 (46.1\%). The dashed and dotted line, however, suggests that a relatively small share of respondents perceive competitive pressure from both FCS and non-traditional lenders. Between 1999 and 2019, an average of $9.6 \%$ of respondents indicate competitive pressure from both lender types, peaking at $16.2 \%$ in 2001 .

\section{Stylized Facts}

The existing literature suggests a number of potential outcomes when lenders face competitive pressure. First, lenders under competitive pressure may lower interest rates to maintain loan volumes (Boyd and De Nicolo, 2005; Martinez-Miera and Repullo, 2010). The interest rate of a loan, however, is not the only characteristic through which lenders can compete for market share. Given that loan rates do not serve the same market-clearing function as prices in standard markets, lenders may also compete along the non-price terms of the lending contract (Jaffee and Stiglitz, 1990). Thus, lenders under competitive pressure may relax the terms of lending to maintain loan volumes. Finally, both the competition-stability and competitionfragility hypotheses suggest that increased competition alters systemic risk in lending markets but to opposite effects. The competition-stability hypothesis suggest that competition leads to overall resiliency in the lending system because competition encourages lenders to take on less risk (Boyd and De Nicolo, 2005; Bushman et al., 2016). By contrast, the competition-fragility hypothesis suggests that competition leads overall fragility in the lending system because competition encourages lenders to take on excessive risk to remain profitable (Keeley, 1990; Bushman et al., 2016). Both hypotheses, however, suggest a significant relationship between competitive pressure and loan portfolio risk.

We examine each potential outcome using data obtained from responses to the Land Values and Credit Conditions Survey. Given the limitations of our data, we stop short of causal interpretation of these findings. Instead, we assert that our analysis yields a number of stylized facts related to competition between commercial banks and non-traditional lenders which provides the basis of our proposed agenda for future research. Our analysis represents an 
important first step toward a better understanding of the impact of competitive pressure from non-traditional lenders on traditional lenders' loan rates, lending terms, and loan portfolio risk.

In addition to these factors, we also examine the relationship between perceived competition and commercial bankers' short-term expectations of farm operating loan volumes. As previously stated, we measure perceived competition through respondents' beliefs of the current loan volume at their bank and at competing lenders (perceived market share). If lenders perceive competitive pressure from other lender types, they may expect market shares to decline further or to revert to prior equilibrium. The expectations of future market share is an important component of the dynamic process linking competition to lender behavior (Keeley, 1990).

\subsection{Methods}

Using our unbalanced panel of Land Values and Credit Conditions Survey responses, we estimate the correlation between perceived competition and (i) loan rates, (ii) lending terms, (iii) loan portfolio risk, and (iv) respondents' loan volume expectations through regression analysis. Our regression analysis exploits the advantages of unbalanced panel data by including both respondent and time fixed effects. Respondent fixed effects control for unobserved heterogeneity among commercial banks related to differences in beliefs, information sets, anchoring of responses (e.g. optimists or pessimists), or unobserved variables that are constant across time (Kuethe and Oppedahl, 2021). Time fixed effects control for changes in economic conditions that are common across all respondents. As a result, the remaining model coefficients represent the average response to changes in the dependent variable with respect to changes in perceived competition.

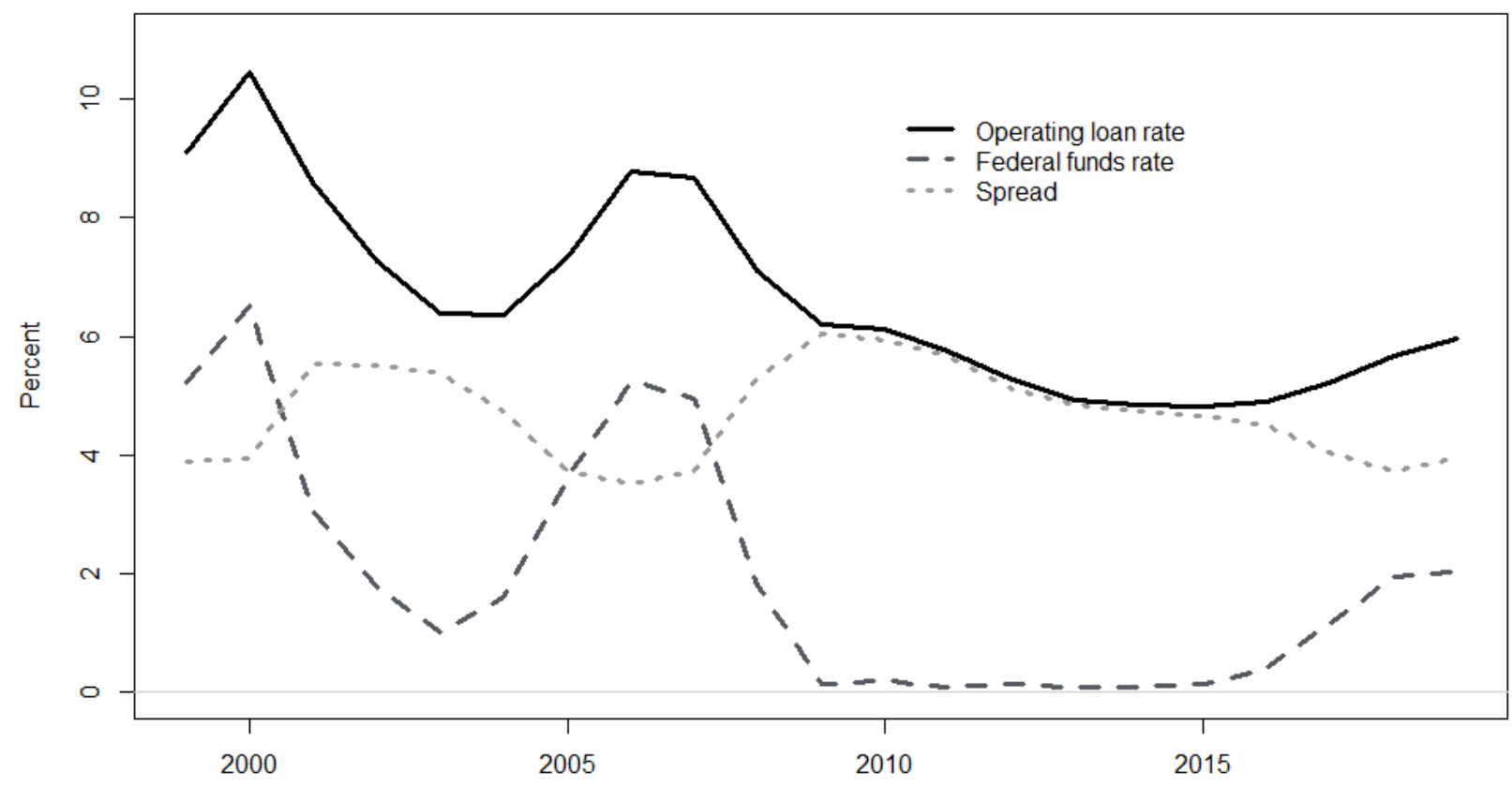

Source: Federal Reserve Bank of Chicago

Figure 5: Mean operating loan rate, effective Federal Funds rate, and spread, 1999-2019 


\section{Loan rates}

The relationship between perceived competition and loan rates is modeled using responses to the following question from the Federal Reserve Bank of Chicago's Land Values and Credit Conditions Survey:

IV. What is the typical interest rate your bank currently charges on operating loans? $\%$.

Following Bushman et al. (2016), we examine the relationship between competitive pressure and the spread between respondents' farm operating loan rate and the effective Federal Funds rate. ${ }^{2}$ Economic theory suggests that in the face of competitive pressures, banks may reduce sensitivity of interest rate spreads to borrower risk in order to maintain their lending volume (Broecker, 1990). Figure 5 plots the mean reported operating loan rate from all respondents (solid line), effective Federal Funds rate (dashed line), and the spread between the two (dotted line).

The relationship between farm operating loan rate spread and perceived competition is represented by the regression equation:

$$
S_{i, t}=\alpha_{i}+\tau_{i}+\beta_{j} C_{i, j, t}+\epsilon_{i, t}
$$

where $S_{i, t}$ is the spread between respondent-reported typical interest on farm operating loans and the effective Federal Funds rate for respondent $i$ in year $t$. The respondent and time fixed effects are represented by $\alpha_{i}$ and $\tau_{t}$. The indicator variable $C_{i, j, t}$ takes the value of 1 if respondent $i$ perceives competitive pressure from lender type $j$ (FCS or non-traditional lenders) in period $t$ and zero otherwise. The relationship between loan rate spread and competitive pressure is captured by the unknown parameters $\beta_{j}$. Following Broecker (1990), regression estimates of $\beta_{j}$ are expected to be negative and statistically significant. Finally, $\epsilon_{i, t}$ is the white noise regression error. Equation (1) can be estimated through ordinary least squares (OLS).

\section{Lending terms}

As previously stated, because loan rates do not serve the same market-clearing function as prices in standard markets, lenders tend to compete along the non-price terms of the lending contract (Jaffee and Stiglitz, 1990). We examine the relationship between perceived competition and non-price terms of the lending contract using responses to the following survey question:

II. What changes occurred in non-real-estate farm loans at your bank in the past three months relative to a year earlier?

Amount of collateral required ........ Higher (1)___ Lower (2)___ Same (3)

Thus, our measure of changes in collateral requirements is qualitative and ordered which complicates the estimation of a regression between collateral requirements and perceived competition.

\footnotetext{
${ }^{2}$ Obtained from Board of Governors of the Federal Reserve System (US), Effective Federal Funds Rate [DFF], retrieved from FRED, Federal Reserve Bank of St. Louis; https://fred.stlouisfed.org/series/ DFF, April $20,2021$.
} 
Following Kuethe and Oppedahl (2021), we assume that the qualitative responses $y_{i, t}$ for individual $i$ at time $t$ are tied to latent, continuous variable $y_{i, t}^{*}$ by the observation rule:

$$
y_{i, t}=k \text { if } \phi_{i, j, k}<y_{i, t}^{*}<\phi_{i, t, k+1}, k=1, \ldots, K
$$

where the individual thresholds $\phi_{i, t}$ are increasing $\left(\phi_{i, t, k} \leq \phi_{i, t, k+1} \forall k\right), \phi_{i, t, 1}=-\infty$, and $\phi_{i, t, K+1}=\infty$. If the qualitative responses are ordered ("lower," "same," and "higher"), the relationship between the qualitative collateral requirement measure $y_{i, t}^{*}$ and perceived competition can be expressed:

$$
y_{i, t}^{*}=\alpha_{i}+\tau_{t}+\beta_{j} C_{i, j, t}+\epsilon_{i, t}
$$

where $y_{i, t}^{*}$ is the ordered, qualitative outcome variable. The remaining terms are the same as (1), except the regression error $\epsilon_{i, t}$ are independent and identically distributed with logistic cumulative distribution function $\Lambda\left(\epsilon_{\mathrm{i}, \mathrm{t}}\right)$.

Equation (2) is estimated using the "blow up and cluster" (BUC) estimator of Baetschmann et al. (2015). The BUC estimator overcomes the complications of estimating an ordered logit model with fixed effects by recoding the original dependent variable $y_{i, t}^{*}$ with $k$ categories into $k-1$ different dichotomizations using $k-1$ thresholds. The original data are "blown up" by duplicating each observation $k-1$ times, one for each dichotomization. Using the blown up data, (2) can be estimated using the conditional logit estimator of Chamberlain (1980). Since observations are dependent by construction, the standard errors need to be clustered at the individual level (Baetschmann et al., 2015). The BUC estimator is not efficient but performs well in small samples (Baetschmann et al., 2015). Through Monte Carlo simulation, Riedl and Geishecker (2014) demonstrate that the BUC estimator delivers the least biased and most efficient estimates of the regression coefficients among competing estimators irrespective of sample size and the number and distribution of ordinal response categories.

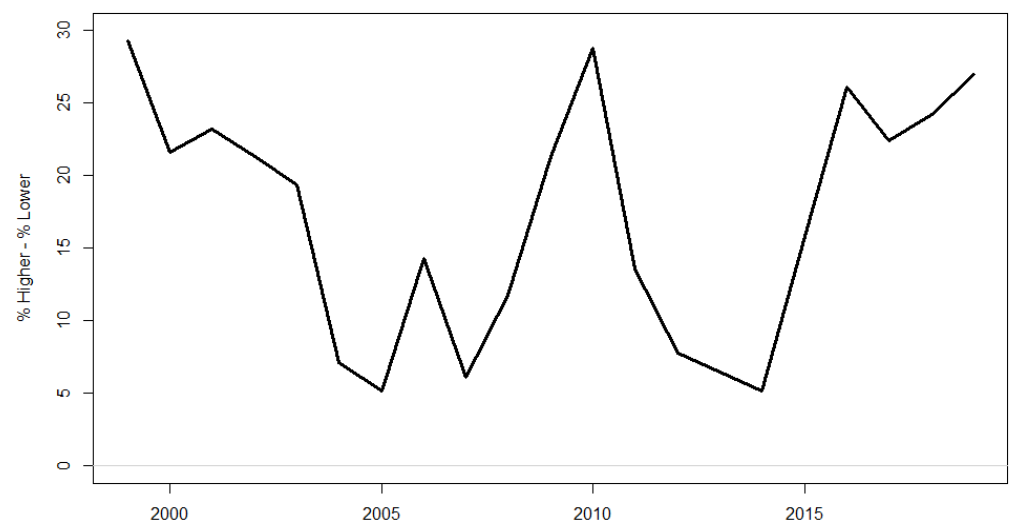

Source: Federal Reserve Bank of Chicago

Figure 6: Collateral requirement balance statistic, 1999-2019

Note: Balance Statistic is calculated as the share of respondents reporting "higher" less the share of respondents reporting "lower" 
Figure 6 plots the balance statistic (percent reporting higher minus percent reporting lower) for collateral requirement across all respondents during our observation period. The balance statistic shows that respondents generally report increasing collateral requirements, but the relative balance between increasing and decreasing collateral requirements fluctuates throughout the observation period.

\section{Loan portfolio risk}

Next, we examine the relationship between perceived competition and commercial banks share of non-performing loans, following Jayaratne and Strahan (1998). The share of nonperforming loans is obtained from the following survey question:

VII. Please indicate the percentage of the dollar amount of your bank's farm loan portfolio that currently falls within each of the following repayment classifications.

No significant repayment problems $\ldots \ldots \ldots \ldots \ldots \ldots \ldots \ldots \ldots \ldots \ldots \ldots \ldots \ldots$

Minor repayment problems which can be remedied fairly easily. . . . . . . . .

Major repayment problems requiring more collateral and/or long-term workouts. . .

Severe repayment problems which will like result in loan losses and/or require forced sales of borrower's real assets . .

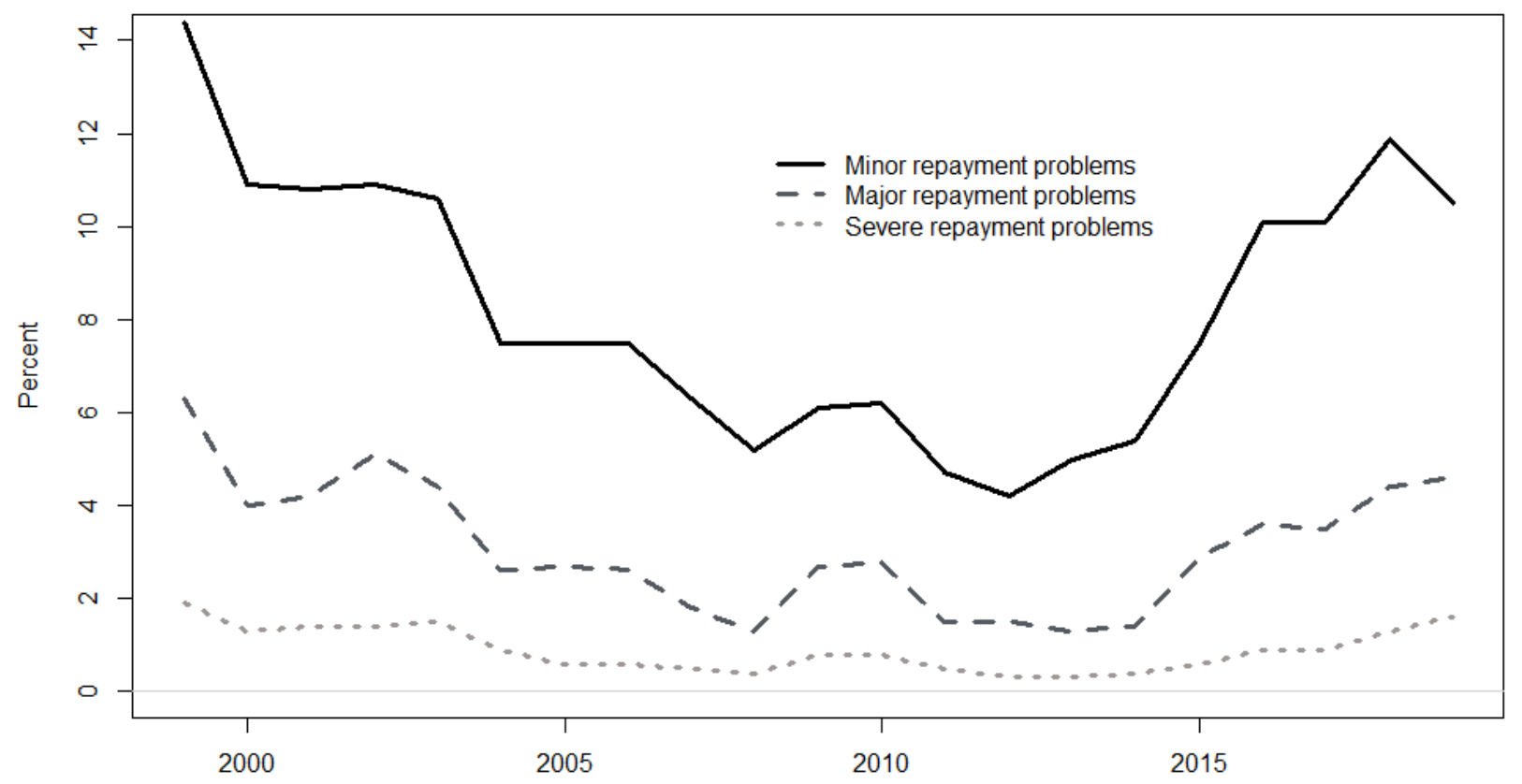

Source: Federal Reserve Bank of Chicago

Figure 7: Mean share of loan portfolio by repayment classification, 1999-2019 
We label these categories (i) no, (ii) minor, (iii) major, and (iv) severe repayment problems, respectively. Figure 7 plots the mean share of loans classified across all respondents for minor, major, and severe repayment problems throughout our observation period. For each category of distressed loans, the share was the highest at the beginning and ending years of our observation period.
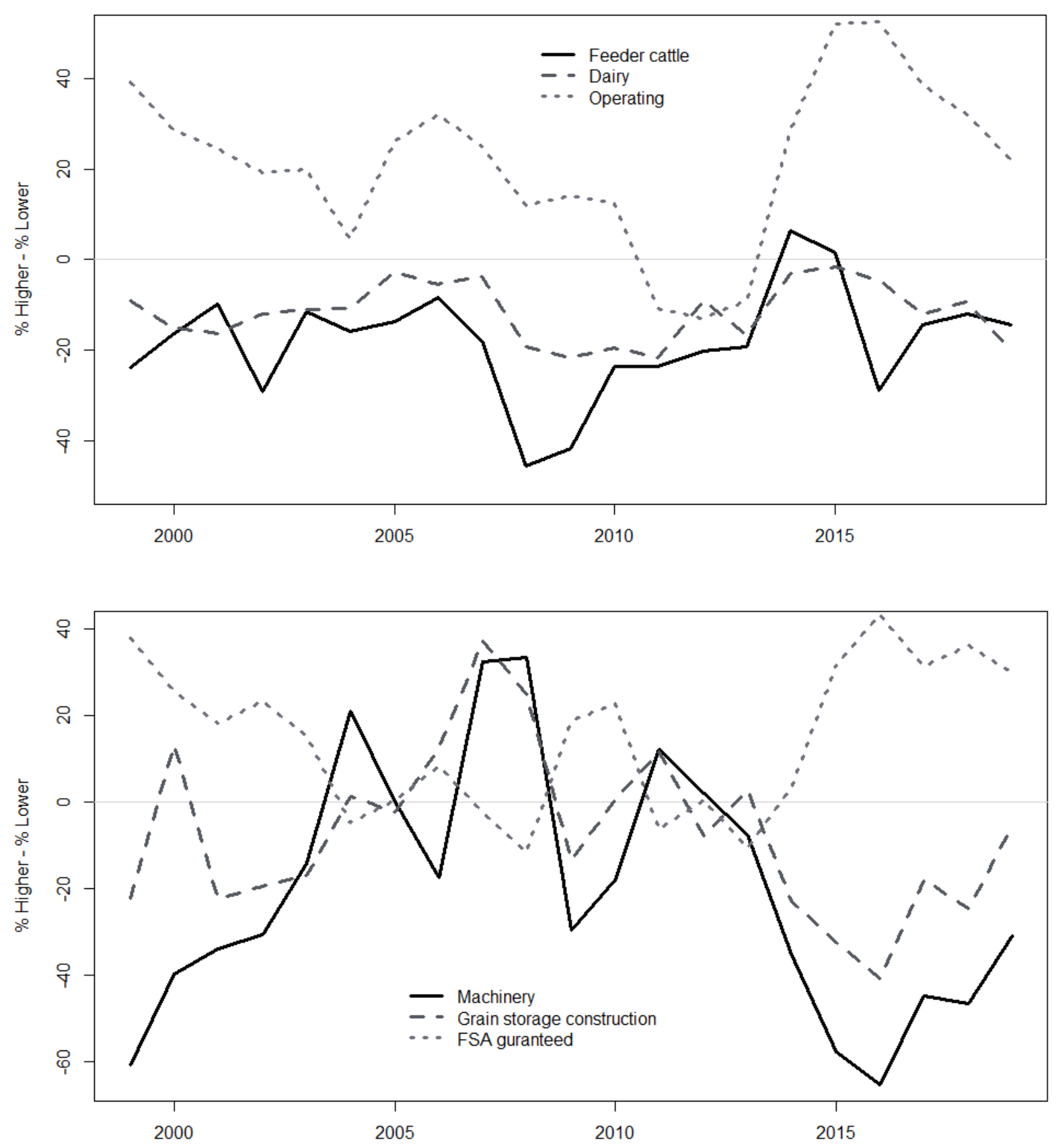

Source: Federal Reserve Bank of Chicago

Figure 8: Expected loan volume balance statistics, 1999-2019

Note: Balance Statistic is calculated as the share of respondents reporting "higher" less the share of respondents reporting "lower" 
The relationship between non-performing loans and perceived competition is also examined through regression analysis in a manner following equation (1). Because the share of total loans in each repayment classification is continuous, the regressions are estimated using OLS.

\section{Expected loan volume}

Finally, we examine the relationship between perceived competition and respondents' short-term expectations of farm operating loan volumes. The expectations are derived from the following multi-part question from the Land Values and Credit Conditions Survey.

III. How do you expect the volume of farm loans made by your bank during July, August, and September [the next quarter] will compare with the volume made during the same months a year ago?

\begin{tabular}{|c|c|c|}
\hline Feeder cattle loans & ; Lower (2) & ; Same (3) \\
\hline Dairy loans & ; Lower (2) & ; Same (3) \\
\hline Operating loans & ; Lower (2) & ; Same (3) \\
\hline Farm machinery loans . . & ; Lower (2) & ; Same (3) \\
\hline Grain storage construction loan & ; Lower (2) & ; Same (3) \\
\hline FSA guaranteed loans & ; Lower (2) & ; Same (3) \\
\hline
\end{tabular}

Similar to collateral requirements, the expectations are qualitative and ordered. As a result, the regressions of loan volume expectations on perceived competition are estimated through BUC regression model in a manner similar to (2). The balance statistic ( $\%$ higher $-\%$ lower) for each farm loan category is plotted in Figure 8.

\subsection{Findings}

\section{Loan rates}

The coefficient estimates for the regression of farm operating loan rate spread on perceived competition are reported in Table 1, along with heteroskedasticity and autocorrelation consistent (HAC) standard errors (Newey and West, 1987). We use two definitions of perceived competition. In the first column, coefficients are estimated for perceived competition from FCS and non-traditional lenders separately. In the second column, a single coefficient is estimated for perceived competition from either FCS or non-traditional lenders. All three estimated coefficients are indistinguishable from zero, which suggests that commercial banks do not respondent to perceived competitive pressure by reducing loan rates or sensitivity to loan rate spreads. This result is counter to the theoretical predictions of Broecker (1990) but is consistent with the belief that loan rates are not constructed in a manner similar to prices in standard markets (Akerlof, 1970; Stiglitz and Weiss, 1981; Jaffee and Stiglitz, 1990). Further, with 
respect to perceived competition with FCS lenders, the insignificant result on loan spread is consistent with Federal law that forbids FCS from offering lower effective interest rates from commercial banks. Specifically, the Federal Credit Act of 1971 states that "in no case is any borrower to be charged a rate of interest that is below competitive market rates for similar loans made by private lenders to borrowers of equivalent creditworthiness and access to alternative credit" (Section 1.1.c).

Table 1: Impact of competition on operating loan rates

\begin{tabular}{|c|c|}
\hline Lender Type & (1) \\
\hline FCS & $\begin{array}{r}-0.074 \\
(0.066)\end{array}$ \\
\hline $\begin{array}{l}\text { Non- } \\
\text { traditional }\end{array}$ & $\begin{array}{r}0.046 \\
(0.057)\end{array}$ \\
\hline Either & $\begin{array}{r}0.014 \\
(0.046)\end{array}$ \\
\hline Banks & 597 \\
\hline Observations & 4,479 \\
\hline
\end{tabular}

\section{Lending terms}

Table 2 similarly reports the coefficient estimates of the regression of collateral requirements on perceived competition. As previously discussed, the ordered responses of the dependent variable require that the regression is estimated using BUC. Following Baetschmann et al. (2015), the reported standard errors are clustered at the respondent-bank level. The coefficient on perceived competition with FCS lenders is statistically significant and negative, which suggests that commercial banks under perceived competitive pressure from FCS lenders have a tendency to lower collateral requirements on non-real estate loans, consistent with Bushman et al. (2016). This finding has important policy implications. Given that FCS lenders are forbidden from offering loan rates below competitive markets rates from private lenders, our results suggest FCS lenders may encourage competition along other non-price terms of the lending contract. In contrast, the coefficient on perceived competition with non-traditional lenders (column 1) or either lender type (column 2) are statistically insignificant. This result suggests that commercial banks do not adjust the non-price terms of the lending contract under competitive pressure from non-traditional lenders. In sum, the results reported in Tables 1 and 2 suggest that commercial bankers who express a loss in farm loan market share to non-traditional lenders do not respond by lowering loan rate spreads or collateral requirements. As a result, it is 
difficult to argue that non-traditional lenders are viewed by commercial banks as a competitive threat.

Table 2: Impact of competition on collateral requirements

\begin{tabular}{lccc}
\hline \hline Lender Type & $(1)$ & & $(2)$ \\
\hline FCS & -0.058 & $* *$ & \\
& $(0.024)$ & & \\
Non- & & & \\
traditional & 0.028 & & \\
& $(0.023)$ & & \\
Either & & & -0.008
\end{tabular}

$\begin{array}{cc}\text { Banks } & 597 \\ \text { Observations } & 4,465 \\ \text { Note: Asterisks represent significance } * * * 1 \%, * * 5 \%, & * 10 \% ; \\ \text { Standard errors are clustered at the respondent level }\end{array}$

\section{Loan portfolio risk}

The regression results for the relationship between perceived competition and share of non-performing loans are reported in table 3 . The first two columns examine the relationship between perceived competition and the share of loans with no significant repayment problems. The estimated coefficients suggest a significant and positive relationship when commercial banks compete with FCS lenders and a significant and negative relationship when commercial banks compete with non-traditional lenders. Specifically, respondents who perceive competitive threat with FCS lenders in their market area report a $1.1 \%$ increase in the share of loans without repayment problems, and respondents who perceive competitive threat from non-traditional lenders in their market area report a $1.5 \%$ decrease in the share of loans without repayment problems.

In other words, the estimation results for loans without repayment problems suggest that loan portfolio quality improves for banks that compete with FCS lenders. However, when commercial banks compete with non-traditional lenders, loan portfolio quality deteriorates. This finding is further supported by regression estimates for perceived competition on the share of loans with minor repayment problems (columns 3 and 4). The estimated coefficients suggest a nearly $1 \%$ decrease in share of loans with minor repayment problems when competing with FCS and a $1 \%$ increase when competing with non-traditional lenders. The estimated coefficients in table 3 may seem small but are potentially economically significant given that the mean of all responses suggests an average of $87.4 \%$ of loans without repayment problems and $8.5 \%$ of loans with minor repayment problems across the observation period. 
Table 3: Impact of competition on farm loan repayment

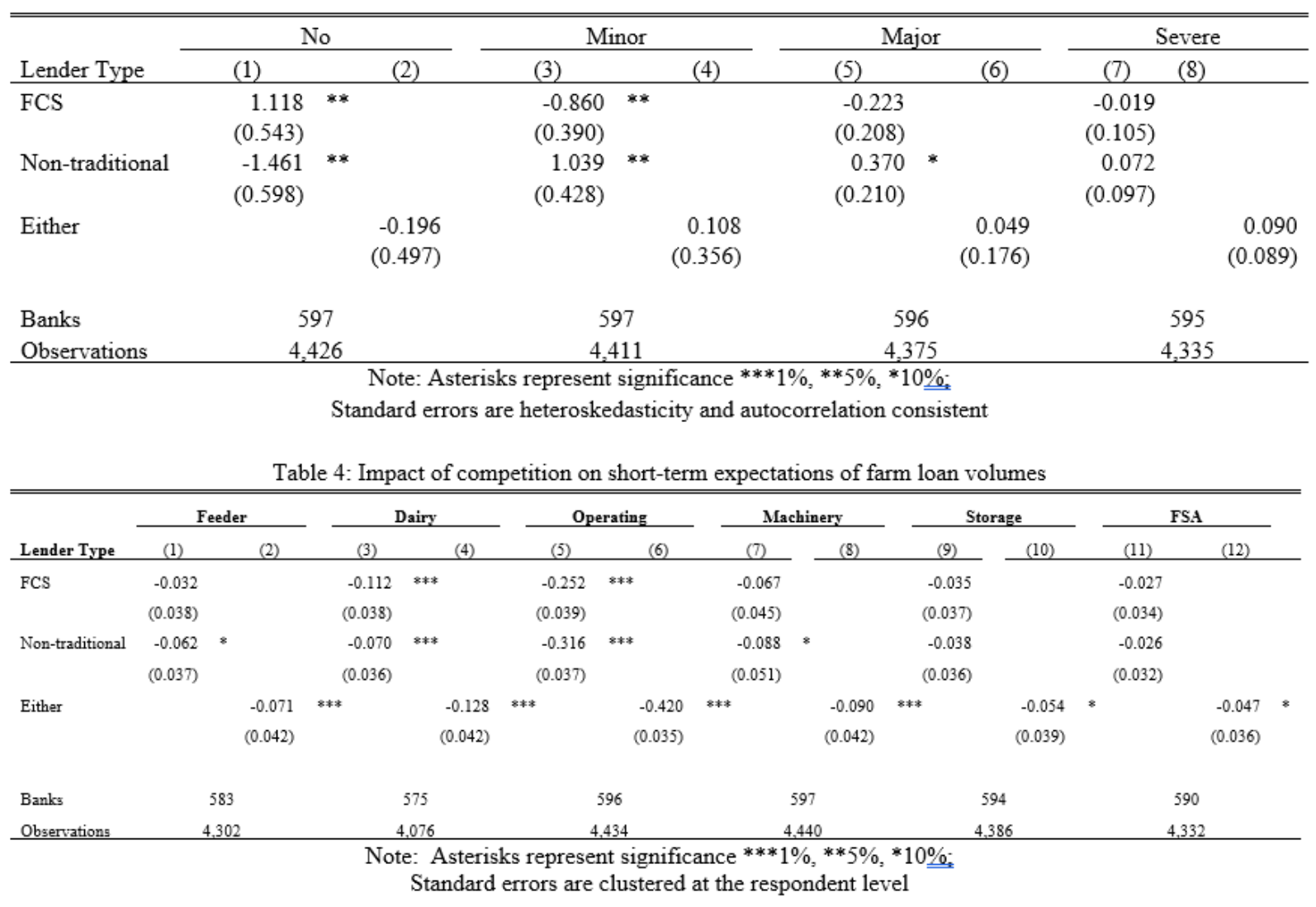

\section{Expected loan volumes}

Finally, table 4 reports the estimated coefficients for the regression of perceived competition on expected loan volumes. The results suggest, in aggregate, that commercial banks who perceived competitive pressure from FCS or non-traditional lenders expect loan volumes to decline for a number of categories. Specifically, commercial banks who perceive competitive pressure from FCS lenders expect reductions in dairy and operating loans. This finding suggests that commercial banks perceive the greatest competitive threat with FCS lenders for these categories of farm loans. In addition, the relationship between perceived competition with nontraditional lenders is also statistically significant for dairy and operating loans and weakly significant (10\% level) for feeder cattle and machinery. In sum, the expectations regressions suggest that commercial banks who perceive competitive pressure from FCS or non-traditional lenders expect continued declines in lending at their institution. This expected decline can be driven by either total declines in agricultural loan volumes or decreased market share to the competing lender types.

\section{An Agenda for Future Research}

This study provides new information that helps fill the gaps in our current understanding of the impact of non-traditional lenders in agricultural loan markets. Specifically, we examine 
the competition between commercial banks and both non-traditional and FCS lenders. Previous studies have examined competition between commercial banks and FCS lenders (Hubbs and Kuethe, 2017; Turvey et al., 2020), yet the competition between commercial banks and nontraditional lenders is relatively unexplored. Research is limited by a lack of empirical data on non-traditional lending, as well as complications of measuring competition in agricultural lending markets (Morris et al., 2015). This gap in current knowledge base persists despite the documented increase in short-term credit from non-traditional lenders (Brewer et al., 2019) and the long-recognized potential of competitive pressure from non-traditional lenders (Sherrick et al., 1994).

We develop a measure of agricultural bankers" "perceived competition" based on an unbalanced panel of responses to the Federal Reserve Bank of Chicago's Land Values and Credit Conditions Survey from 1999 through 2019. We define perceived competition as instances in which respondents report stable or decreasing loan volumes at their institution and increasing loan volumes from FCS or non-traditional lenders. This measure suggests that roughly one-infive respondents, on average, perceive competitive pressure from FCS or non-traditional lenders, but the relative competitive pressure from these two lenders types fluctuates throughout the observation period.

Regression analysis yields a number of stylized facts. We find that perceived competition with FCS lenders is associated with relaxed collateral requirements but no change is observed for loan rate spreads. In addition, perceived competition with FCS is associated with less risky farm loan portfolios at commercial banks. In contrast, perceived competition is associated with riskier farm loan portfolios. Finally, commercial banks expect loan volume decreases when they perceive competition with either FCS or non-traditional lenders.

In aggregate, these stylized facts provide mixed evidence that commercial banks compete with non-traditional lenders. While perceived competition with non-traditional lenders is associated with higher share of farm loans that are delinquent and lower expected operating loan volumes, commercial banks do not appear to adjust loan rates or terms in response to perceived competition. These findings, however, highlight the need for continued research on agricultural lending market competition that considers both traditional and non-traditional lenders.

Our empirical analysis is subject to a number of limitations and constraints that could be addressed in future research. First, the respondent pool of the Federal Reserve Bank of Chicago's Land Values and Credit Conditions Survey is limited to commercial bankers, and as a result, we are unable to gauge the level of perceived competition by other lender types, such as FCS lenders. In addition, our study also fails to capture perceived competition from other commercial banks, an important source of competition in agricultural lending markets (Regmi and Featherstone, 2021). Future research could explore these additional dimensions of perceived competition. 
Second, our measure of perceived competition deserves further study. The measure was developed from two disparate strands of the literature. The first strand of literature uses surveybased measures of competition in other sectors of the economy (Haskel and Martin, 1994; Nickell, 1996; Dedman and Lennox, 2009). The second uses text-analysis to measure perceptions of competitive pressure from any and all sources (including non-bank sources) that are not yet fully reflected in bank's past performance (Bushman et al., 2016). As summarized by Claessens (2009), the existing literature offers a number of alternative measures of lending market competition, and these measures have been used to study competition in agricultural lending markets (Morris et al., 2015; Kandilov and Kandilov, 2018; Regmi and Featherstone, 2021). Future research could use survey based measures of competition in combination with administrative information, such as call reports, to examine the degree to which perceived competition predicts risks ahead of bank performance measure. Administrative data could also provide a richer set of control variables to examine potential heterogeneity in responses related to bank size, location, or other characteristics.

A similar vein of research could explore competition using a combination of survey competition measures and loan-level information on interest rates and borrowing terms. Detailed loan-level data or matched borrower-lender data could provide information that cannot be obtained from the Land Values and Credit Conditions Survey. For example, we are unable to estimate the degree to which changes in loan delinquencies is associated with changes in the mix of borrowers or a deterioration in existing borrowers' financial position. The differences in loan portfolios may reflect differences in the underlying population of borrowers served by FCS or non-traditional lenders, and previous research suggests a number of farmer characteristics are associated with the decision to borrow from commercial banks, FCS, or non-traditional lenders. For example, FCS lenders are more likely to serve larger, wealthier, and more established farmers (Dodson and Koenig, 2004), and farmers who borrow only from non-traditional lenders are younger, have more machinery and equipment, and own less land (Brewer et al., 2019). Further, we are unable to identify whether borrowers are switching between commercial banks and competing lenders or borrowing from a combination of lenders.

In sum, more research is needed on the competition between traditional and nontraditional lenders. Competition in agricultural lending markets is an important component of U.S. agricultural policy. The FCS, for example, was explicitly designed to increase competition in agricultural lending markets (Lee and Irwin, 1996; Jensen, 2000). In addition, the regulatory mosaic between various agricultural credit suppliers has been said to create periodic imbalances in agricultural loan markets (Barry, 1995). The largely unregulated lending by non-traditional credit suppliers is difficult to observe directly (Sherrick et al., 1994), but our study shows that further study is warranted. 


\section{References}

Akerlof, G. A. (1970). The market for "lemons": Quality uncertainty and the market mechanism. The Quarterly Journal of Economics 84 (3), 488-500.

Baetschmann, G., K. E. Staub, and R. Winkelmann (2015). Consistent Estimation of the Fixed Effects Ordered Logit Model. Journal of the Royal Statistical Society: Series A (Statistics in Society) 178 (3), 685-703.

Barry, P. J. (1995). The Effects of Credit Policies on US Agriculture. American Enterprise Institute.

Barry, P. J., R. W. Bierlen, and N. L. Sotomayor (2000). Financial structure of farm businesses under imperfect capital markets. American Journal of Agricultural Economics 82 (4), 920 933.

Bassett, W. F., M. B. Chosak, J. C. Driscoll, and E. Zakrašek (2014). Changes in bank lending standards and the macroeconomy. Journal of Monetary Economics 62, 23-40.

Berger, A. N., L. F. Klapper, and R. Turk-Ariss (2017). Bank competition and financial stability. In Handbook of Competition in Banking and Finance. Edward Elgar Publishing.

Bierlen, R. and A. M. Featherstone (1998). Fundamental q, cash flow, and investment: evidence from farm panel data. Review of Economics and Statistics 80 (3), 427-435.

Boyd, J. H. and G. De Nicolo (2005). The theory of bank risk taking and competition revisited. The Journal of Finance 60 (3), 1329-1343.

Brewer, B. E., J. S. Bergtold, A. M. Featherstone, and C. A. Wilson (2019). Farmers' choice of credit among the farm credit system, commercial banks, and nontraditional lenders. Journal of Agricultural and Resource Economics 44 (1835-2019-1556), 362-379.

Briggeman, B. C., S. R. Koenig, C. B. Moss, et al. (2012). Us farm debt: the role of arms. Agricultural Finance Review 72 (2), 254-261.

Briggeman, B. C., C. A. Towe, and M. J. Morehart (2009). Credit constraints: their existence, determinants, and implications for us farm and nonfarm sole proprietorships. American Journal of Agricultural Economics 91 (1), 275-289.

Broecker, T. (1990). Credit-worthiness tests and interbank competition. Econometrica: Journal of the Econometric Society, 429-452.

Bushman, R. M., B. E. Hendricks, and C. D. Williams (2016). Bank competition: Measurement, decision-making, and risk-taking. Journal of Accounting Research 54 (3), 77

Chamberlain, G. (1980). Analysis of Covariance with Qualitative Data. Review of Economic Studies, 225-238.

Ciccarelli, M., A. Maddaloni, and J.-L. Peydró (2015). Trusting the bankers: A new look at the credit channel of monetary policy. Review of Economic Dynamics 18 (4), 979-1002.

Claessens, S. (2009). Competition in the financial sector: Overview of competition policies. The World Bank Research Observer 24 (1), 83-118.

Claessens, S. and L. Laeven (2004). What drives bank competition? some international evidence. Journal of Money, Credit and Banking, 563-583. 
Dedman, E. and C. Lennox (2009). Perceived competition, profitability and the withholding of information about sales and the cost of sales. Journal of Accounting and Economics 48 (2-3), 210-230.

Del Giovane, P., G. Eramo, and A. Nobili (2011). Disentangling demand and supply in credit developments: a survey-based analysis for Italy. Journal of Banking \& Finance 35 (10), 2719-2732.

Dodson, C. B. and S. R. Koenig (2004). Competition in farm credit markets: identifying market segments served by the farm credit system and commercial banks. Agricultural Finance Review.

Federal Reserve Bank of Kansas City (2020). Agricultural Finance Databook. Technical report.

Haskel, J. and C. Martin (1994). Capacity and competition: Empirical evidence on uk panel data. The Journal of Industrial Economics, 23-44.

Hubbs, T. and T. Kuethe (2017). A disequilibrium evaluation of public intervention in agricultural credit markets. Agricultural Finance Review.

Jaffee, D. and J. Stiglitz (1990). Credit rationing. Handbook of Monetary Economics 2, 837-888.

Jayaratne, J. and P. E. Strahan (1998). Entry restrictions, industry evolution, and dynamic efficiency: Evidence from commercial banking. The Journal of Law and Economics 41 (1), 239-274.

Jensen, F. E. (2000). The farm credit system as a government-sponsored enterprise. Review of Agricultural Economics 22 (2), 326-335.

Jiménez, G., J. A. Lopez, and J. Saurina (2013). How does competition affect bank risktaking? Journal of Financial Stability 9 (2), 185-195.

Kandilov, A. M. and I. T. Kandilov (2018). The impact of bank branching deregulations on the us agricultural sector. American Journal of Agricultural Economics 100 (1), 73-90.

Keeley, M. C. (1990). Deposit insurance, risk, and market power in banking. The American Economic Review, 1183-1200.

Kuethe, T. H. and D. Oppedahl (2021). Agricultural bankers' farmland price expectations. European Review of Agricultural Economics 48 (1), 42-59.

Lee, W. F. and G. D. Irwin (1996). Restructuring the farm credit system: a progress report. Agricultural Finance Review 56, 1-21.

Li, F., R. Lundholm, and M. Minnis (2013). A measure of competition based on 10-k filings. Journal of Accounting Research 51 (2), 399-436.

Lown, C. and D. P. Morgan (2006). The credit cycle and the business cycle: new findings using the loan officer opinion survey. Journal of Money, Credit and Banking, 1575-1597.

Martinez-Miera, D. and R. Repullo (2010). Does competition reduce the risk of bank failure? The Review of Financial Studies 23 (10), 3638-3664.

Morris, C. S., J. Wilkinson, and E. Hogue (2015). Competition in local agricultural lending markets: The effect of the farm credit system. Economic Review-Federal Reserve Bank of Kansas City, 51. 
Moss, L. M., P. J. Barry, and P. N. Ellinger (1997). The competitive environment for agricultural bankers in the us. Agribusiness: An International Journal 13 (4), 431-444.

Newey, W. K. and K. D. West (1987). A Simple, Positive Semi-Definite, Heteroskedasticity and Autocorrelation Consistent Covariance Matrix. Econometrica 55 (3), 703-708.

Nickell, S. J. (1996). Competition and corporate performance. Journal of Political Economy 104 (4), 724-746.

Regmi, M. and A. Featherstone (2021). Competition, Performance and Financial Stability in the U.S. Agricultural Banking. Agricultural Finance Review, forthcoming.

Riedl, M. and I. Geishecker (2014). Keep it Simple: Estimation Strategies for Ordered Response Models with Fixed Effects. Journal of Applied Statistics 41 (11), 2358-2374.

Sherrick, B. J., S. T. Sonka, and J. D. Monke (1994). Nontraditional lenders in agricultural credit markets. Agribusiness 10 (4), 341-357.

Stiglitz, J. E. and A. Weiss (1981). Credit rationing in markets with imperfect information. The American Economic Review 71 (3), 393-410.

Tseng, J. (2020). How do finance companies' advantages affect competitive strategies in shortand intermediate-term loan markets? a theoretical analysis. International Journal of Finance \& Economics.

Turvey, C. G., A. Carduner, and J. Ifft (2020). Market microstructure and the historical relationship between the us farm credit system, farm service agency and commercial bank lending. Agricultural Finance Review.

USDA Economic Research Service (2021). 2021 Farm Sector Balance Sheet. United States Department of Agriculture, Economic Research Service, Washington, DC. 